\title{
Dopamine-NMDA Receptor Interactions: Twenty Years Later
}

\author{
Carlos Cepeda Michael S. Levine
}

Intellectual and Developmental Disabilities Research Center, David Geffen School of Medicine, University of

California Los Angeles, Los Angeles, Calif., USA

The classic paper discussed in this essay:

Cepeda C, Levine MS: Dopamine and N-methyl-D-aspartate receptor interactions in the neostriatum. Dev Neurosci 1998;20:1-18.

\section{Introduction}

In 1998, we published a review in Developmental Neuroscience which detailed the path to our discovery of differential effects of dopamine (DA) on glutamate-evoked responses and discussed its functional relevance [1]. Although several papers had already been published on DAglutamate interactions, our review was among the first to focus exclusively on DA and N-methyl-D-aspartate (NMDA) receptor interactions. As such, this review became a classic, with more than 15 citations every year. Here, we revisit the question of DA-NMDA receptor interactions in the light of recent studies that provide novel information on this complex issue.

\section{The Discovery}

Twenty years ago, we discovered that DA modulates glutamate receptor-evoked responses differentially. Thus, while responses mediated by activation of $\alpha$-amino-3-hydroxy-5-methyl-4-isoxazolepropionic acid (AMPA) receptors were decreased, responses mediated by NMDA receptors were enhanced [2]. When selective DA receptor agonists were used, we observed that, for the most part, activation of D1 receptors potentiated glutamate responses, in particular those mediated by NMDA receptors, whereas activation of $\mathrm{D} 2$ receptors attenuated glutamate responses, in particular those mediated by AMPA receptors [2]. At the time, the prevailing wisdom was that DA acted as an inhibitory neurotransmitter to depress spontaneous or glutamate-induced firing, although there was evidence for mixed effects which were correctly attributed to different DA receptor subtypes. Thus, the idea that DA functioned as a classical inhibitory neurotransmitter, such as GABA, was challenged. In agreement, the current consensus is that DA acts as a modulator that alters the responses evoked by excitatory and inhibitory neurotransmitters.

Further studies in our laboratory demonstrated the importance of the cAMP-PKA-DARPP-32 cascade in the induction of differential effects by DA in striatal medium-sized spiny neurons (MSNs) [3]. While modulation of voltage-gated currents by DA also played a role in the enhancement of NMDA currents [4], modulation occured even when voltage-gated currents were blocked [3]. The most parsimonious hypothesis was that the interplay between ligand- and voltage-gated currents was responsible for DA receptor-mediated differential effects. To complete the picture, we also demonstrated that DA ex-

\section{KARGER}

Fax +4161306 1234 E-Mail karger@karger.ch www.karger.com (c) 2012 S. Karger AG, Basel

0378-5866/12/0341-0002\$38.00/0

Accessible online at:

www.karger.com/dne
Carlos Cepeda, $\mathrm{PhD}$

Intellectual and Developmental Disabilities Research Center

Semel Institute for Neuroscience, Room 58-258, UCLA School of Medicine

760 Westwood Plaza, Los Angeles, CA 90024 (USA)

Tel. +1 310206 0861, E-Mail ccepeda @ mednet.ucla.edu 
erts presynaptic effects and regulates glutamate release via activation of $\mathrm{D} 2$ receptors located on corticostriatal axon terminals [5]. Together, these pre- and postsynaptic actions of DA underlie a number of synergistic actions that have important implications for setting membrane potentials, improving the signal-to-noise ratio, and synaptic plasticity.

\section{Confirmatory and Dissident Voices}

While the discovery of differential modulation of glutamate responses by DA was met with some resistance, the overwhelming evidence has been in favor of our paradigm. In the cerebral cortex $[6,7]$ and nucleus accumbens [8], the great majority of studies replicated our main findings. The dissident voices can be divided into two groups: those that claimed that DA does not affect glutamate transmission $[9,10]$, and those that, while accepting the observation, claimed that the underlying mechanisms are indirect, e.g. via modulation of voltage-gated channels, and have little to do with direct glutamate receptor modulation [11]. The two studies that did not observe DA effects readily acknowledged that procedural differences could have prevented modulation. The other criticisms of the proposed paradigm [11] appear to be due to misinterpretations of the original literature.

\section{Mechanisms}

Important strides have been made to understand the intracellular signaling cascades underlying D1 receptor enhancement of NMDA responses. In addition to demonstrating a critical role of the cAMP-PKA-DARPP-32 cascade in the induction of differential effects by DA in striatal MSNs [3], other studies have underlined the effects of DA and its agonists on glutamate receptors. For example, activation of D1 receptors enhances surface expression of NMDA and AMPA receptors [12, 13]. D1 receptor activation also increases NR1, NR2A, and NR2B proteins in the synaptosomal membrane fraction, an effect that is dependent on Fyn protein tyrosine kinase [14]. Evidence also suggests that D1 and NMDA receptors are assembled as oligomeric units in the endoplasmic reticulum and transported to the cell surface as a preformed complex [15]. In the cerebral cortex, it was shown that the enhancement of NMDA responses by D1 agonists occurred via suppression of $\mathrm{Ca}^{2+} /$ calmodulin-dependent inactivation of NMDA channels [16], although a role for the PKA cascade was also demonstrated [17]. In the nucleus accumbens, activation of D1 receptors potentiated NMDA responses in a subset of neurons via protein kinase $\mathrm{C}$ activation [8]. DA modulation of intracellular cascades, in conjunction with modulation of voltage-gated currents, conform a series of cooperative and redundant mechanisms to achieve a common goal: the enhancement of NMDA-evoked responses.

\section{The Current Status of DA-NMDA Receptor Interactions}

The generation of mice expressing enhanced green fluorescent protein (EGFP) in direct and indirect pathway MSNs, and the use of optogenetics, opened a new era. For the first time, it became possible to identify D1 and D2 receptor-expressing cells before electrophysiological recordings were made and to modulate the activity of specific neuronal populations by expression of excitatory and inhibitory opsins. In addition, these new technologies provided strong evidence that D1 and D2 DA receptors were segregated on different populations of striatal MSNs and ended the controversy about the degree of DA receptor colocalization $[18,19]$.

In our most recent studies we used mice expressing EGFP in D1 and D2 receptor-containing cells to examine DA receptor modulation of MSNs of the direct and indirect pathways [20,21]. As expected, D1 enhancement of glutamate responses was specific to direct pathway neurons, whereas D2 attenuation of responses was specific to indirect pathway MSNs [20]. In addition, presynaptic modulation of glutamate was demonstrated to occur in both neuronal populations but D2 depression of glutamate release was more selective for indirect pathway neurons whereas D1 increases were selective for direct pathway MSNs [20, 21]. For this modulation to occur, particularly the enhancement of glutamate release by $\mathrm{D} 1$ agonists, endocannabinoids play an important role. More recently, we demonstrated that D1 enhancement of NMDA responses is significantly reduced in mice with genetic knock-down of NR1 subunits. In addition, whereas genetic deletion or pharmacological blockade of NR2A subunits enhanced D1 potentiation of NMDA responses, blockade of NR2B subunits reduced this potentiation, indicating that these regulatory subunits of the NMDA receptor counterbalance their respective functions [22].

Finally, in a series of elegant experiments combining patch clamp recordings, $\mathrm{Ca}^{2+}$ imaging, optogenetics, and glutamate uncaging, Higley and Sabatini [23] corrobo- 
rated some of the main tenets of our hypothesis, namely, that $\mathrm{D} 2$ receptors decrease NMDA-induced responses. In addition, their use of optogenetics to selectively stimulate corticostriatal terminals demonstrated, beyond any doubt, the presynaptic modulation of glutamate release.

DA-NMDA receptor interactions have proven fertile ground for understanding how DA modulates the actions of other neurotransmitters, with important implications for drug targeting in movement disorders, addiction, and schizophrenia. Twenty years after the original discovery, our paradigm explaining these interactions remains val- id. With the introduction of optogenetics to selectively manipulate neuronal activity of select neuronal populations with light, the future of DA-NMDA receptor interactions is still bright.

\section{Acknowledgments}

The series of studies on DA-glutamate receptor interactions and the present communication were funded by USPHS grant NS33538. The authors would like to thank Elizabeth A. Wang for making corrections and suggestions on the manuscript.

\section{References}

1 Cepeda C, Levine MS: Dopamine and Nmethyl-D-aspartate receptor interactions in the neostriatum. Dev Neurosci 1998;20:118.

-2 Cepeda C, Buchwald NA, Levine MS: Neuromodulatory actions of dopamine in the neostriatum are dependent upon the excitatory amino acid receptor subtypes activated. Proc Natl Acad Sci USA 1993;90:9576-9580.

\3 Flores-Hernandez J, Cepeda C, HernandezEcheagaray E, Calvert CR, Jokel ES, Fienberg AA, Greengard P, Levine MS: Dopamine enhancement of NMDA currents in dissociated medium-sized striatal neurons: role of D1 receptors and DARPP-32. J Neurophysiol 2002;88:3010-3020.

4 Cepeda C, Colwell CS, Itri JN, Chandler SH, Levine MS: Dopaminergic modulation of NMDA-induced whole cell currents in neostriatal neurons in slices: contribution of calcium conductances. J Neurophysiol 1998;79: 82-94.

5 Cepeda C, Hurst RS, Altemus KL, FloresHernandez J, Calvert CR, Jokel ES, Grandy DK, Low MJ, Rubinstein M, Ariano MA et al: Facilitated glutamatergic transmission in the striatum of D2 dopamine receptor-deficient mice. J Neurophysiol 2001;85:659-670.

-6 Seamans JK, Yang CR: The principal features and mechanisms of dopamine modulation in the prefrontal cortex. Prog Neurobiol 2004; $74: 1-58$.

7 Tseng KY, O’Donnell P: Dopamine-glutamate interactions controlling prefrontal cortical pyramidal cell excitability involve multiple signaling mechanisms. J Neurosci 2004; 24:5131-5139.

8 Chergui K, Lacey MG: Modulation by dopamine D1-like receptors of synaptic transmission and NMDA receptors in rat nucleus accumbens is attenuated by the protein kinase C inhibitor Ro 32-0432. Neuropharmacology $1999 ; 38: 223-231$.
-9 Calabresi P, De Murtas M, Pisani A, Stefani A, Sancesario G, Mercuri NB, Bernardi G: Vulnerability of medium spiny striatal neurons to glutamate: role of $\mathrm{Na}+/ \mathrm{K}+$ ATPase. Eur J Neurosci 1995;7:1674-1683.

10 Nicola SM, Malenka RC: Modulation of synaptic transmission by dopamine and norepinephrine in ventral but not dorsal striatum. J Neurophysiol 1998;79:1768-1776

11 Surmeier DJ, Carrillo-Reid L, Bargas J: Dopaminergic modulation of striatal neurons, circuits, and assemblies. Neuroscience 2011 198:3-18.

12 Hallett PJ, Spoelgen R, Hyman BT, Standaert DG, Dunah AW: Dopamine D1 activation potentiates striatal NMDA receptors by tyrosine phosphorylation-dependent subunit trafficking. J Neurosci 2006;26:4690-4700.

13 Snyder GL, Allen PB, Fienberg AA, Valle CG, Huganir RL, Nairn AC, Greengard P: Regulation of phosphorylation of the GluR1 AMPA receptor in the neostriatum by dopamine and psychostimulants in vivo. J Neurosci 2000;20:4480-4488

14 Dunah AW, Sirianni AC, Fienberg AA, Bastia E, Schwarzschild MA, Standaert DG: Dopamine D1-dependent trafficking of striatal $\mathrm{N}$-methyl-D-aspartate glutamate receptors requires Fyn protein tyrosine kinase but not DARPP-32. Mol Pharmacol 2004;65:121129.

15 Fiorentini C, Gardoni F, Spano P, Di Luca M Missale C: Regulation of dopamine D1 receptor trafficking and desensitization by oligomerization with glutamate N-methylD-aspartate receptors. J Biol Chem 2003;278: 20196-20202.
16 Chen G, Greengard P, Yan Z: Potentiation of NMDA receptor currents by dopamine D1 receptors in prefrontal cortex. Proc Natl Acad Sci USA 2004;101:2596-2600.

17 Wang J, O’Donnell P: D(1) dopamine receptors potentiate nmda-mediated excitability increase in layer $\mathrm{V}$ prefrontal cortical pyramidal neurons. Cereb Cortex 2001;11:452462 .

18 Gerfen CR, Engber TM, Mahan LC, Susel Z, Chase TN, Monsma FJ Jr, Sibley DR: D1 and D2 dopamine receptor-regulated gene expression of striatonigral and striatopallidal neurons. Science 1990;250:1429-1432.

19 Surmeier DJ, Eberwine J, Wilson CJ, Cao Y, Stefani A, Kitai ST: Dopamine receptor subtypes colocalize in rat striatonigral neurons. Proc Natl Acad Sci USA 1992;89:1017810182

20 Andre VM, Cepeda C, Cummings DM, Jocoy EL, Fisher YE, William Yang X, Levine MS: Dopamine modulation of excitatory currents in the striatum is dictated by the expression of D1 or D2 receptors and modified by endocannabinoids. Eur J Neurosci 2010; 31:14-28.

21 Cepeda C, Andre VM, Yamazaki I, Wu N, Kleiman-Weiner M, Levine MS: Differential electrophysiological properties of dopamine D1 and D2 receptor-containing striatal medium-sized spiny neurons. Eur J Neurosci 2008;27:671-682

22 Jocoy EL, André VM, Cummings DM, Rao SP, Wu N, Ramsey AJ, Caron M, Cepeda C, Levine MS: Dissecting the contribution of individual receptor subunits to the enhancement of N-methyl-D-aspartate currents by dopamine D1 receptor activation in striatum. Front Syst Neurosci 2011;5:28.

$\checkmark 23$ Higley MJ, Sabatini BL: Competitive regulation of synaptic $\mathrm{Ca} 2+$ influx by $\mathrm{D} 2$ dopamine and $\mathrm{A} 2 \mathrm{~A}$ adenosine receptors. Nat Neurosci 2010;13:958-966 